\title{
Pension Funds, the Requirement of Providing the Minimum Guaranteed Return and Excessive Legislative Restrictions of Pension Fund Investments
}

Tanja Markovič Hribernik, Igor Jakopanec*

\section{Abstract:}

To reduce the exposure of the pension fund's members to financial risks, legislation in Slovenia and some other countries promises a so-called minimum guaranteed return and at the same time hinders the portfolio diversification process of pension funds. We intend to demonstrate in this article, on a case study basis and using a combination of empirical data from two Slovenian pension funds and a hypothetical one, that by precisely matching the investments' characteristics to the characteristics of the pension fund's liabilities, some important financial risks can be mitigated, while others can even be hedged entirely. We also intend to demonstrate that with the implementation of a proper policy of risk measurement and management, complemented with stress testing practices, excessive legislative restrictions for investments are no longer necessary. Some restrictions can even hinder portfolio diversification and the risk management process.

Keywords: pension funds, minimum guaranteed return, asset-liability management, risk management, portfolio regulation, Slovenia

JEL: G11, G23

DOI: 10.2478/v10033-012-0011-9

\section{Introduction}

For the last decade, developed countries have been facing a growing demographic problem. As life expectancy increases, the average age of the population continues rising. There are more and more elderly people and governments have already been forced to reduce first pillar pension benefits. Every individual will be encouraged to cover the difference by saving for extra pension benefits. The managers of pension funds are therefore faced with increasing responsibility for the profitable and - mostly - prudent management of their members' assets.

To reduce the exposure of the pension fund's members to financial risks, legislation in some countries promises a so-called minimum guaranteed return and at the same time hinders the portfolio diversification process of pension funds. If the portfolio manager takes excessive risks and earns negative returns, the difference between the actual (negative) return and the minimum guaranteed return must be covered from his or her own capital. As managers are discouraged to put their solvency at risk, a more conservative approach to investment policy is preferred, which is often associated with relatively poor potential returns and the reduced interest of employed people in participating in supplementary pension savings.

\footnotetext{
* Tanja Markovič Hribernik

University of Maribor, Faculty of Economics and

Business, Slovenia

E-mail: tanja.markovic@uni-mb.si

Igor Jakopanec

Moja naložba, pension fund d.d - Group Nova KBM,

Slovenia

E-mail: igor.jakopanec@moja-nalozba.si
} 
The purpose of this article is a detailed analysis of the connection between the requirement of providing the minimum guaranteed return and managing financial risks on the one hand, and the investment structure of pension funds on the other. On a case study basis, and using a combination of empirical data from two Slovenian pension funds and a hypothetical one, we will demonstrate that by using an asset-liability management (ALM) approach, complemented with stress testing practices, excessive legislative restrictions for investments are no longer necessary.

In portfolio management, the ALM strategy became important after 2001, when shocks on the stock exchange due to events connected with September 11 in the U.S. severely reduced numerous pension funds' available resources for covering liabilities. However, the history of ALM models is longer. The earliest ALM models in literature were deterministic models and duration matching techniques and were applied to find the best portfolio. The stream of future benefit payments was assumed to be known in advance with certainty. Examples of these models are those of Macaulay (developed in 1938), Redington (developed in 1952) and Bierwag et al. (developed in 1983). These models, in which only bonds were considered as possible investments, were used until the mid 1980s. After that, bond models were used in which the future stream of benefit payments were stochastic. However, alternative portfolios were again found by duration matching techniques. Examples of these models are those by Fabozzi and Fabozzi (1989), Cox, Ingersoll and Ross (1985), Jacob, Lord and Tilley (1987) and Norris and Epstein (1989). Duration matching techniques have some major drawbacks. One of them is if interest rates change unexpectedly. Then reinvestment risk has to be considered. In addition, these types of models are extremely sensitive to the specific term structure model used.

In the late 1980s the first integrated analyses for ALM problems were made, using simulation models (see for example Van der Meer (1989) and Boender, van Aalst and Heemskerk (1998)). The added value of these models is the ability to use many scenarios. A major drawback of the simulation techniques is that many choices with respect to policies have to be kept fixed. To overcome the drawbacks of simulation, stochastic linear programming models (SLP) were used to tackle ALM problems. Instead of exogenous variables, as in simulation, decisions become endogenous. While simulation is based on evaluation, SLP is based on optimization (i.e., searches for the best solution). For applications of stochastic programming in ALM for pension funds see for example Consigli and Dempster (1998), Dert (1995), Kouvenberg (2001), Hilli et al. (2003) and Dupacova and Polivka (2009). Even this technique is not without constraint. The major one is its relatively long solution time, which is also the reason why the simulation technique is usually used in practice.

In this paper we will use the simulation technique. In order to evaluate the negative impact of unlikely events on a portfolio, stress tests will be also used. The paper is organized as follows. In section 2 the theoretical background is given, where circumstances that turn more attention to ALM in recent years are also given. In section 3 the data are explained and empirical analysis, i.e. simulation, is done. The methodological framework is included in section 3 as readers can better follow the steps of the simulation. A discussion of the results and recommendations are given in section 4. Finally, some concluding remarks are given in section 5 .

\section{Theoretical Background}

\subsection{Pension plans and investment objectives}

Pension funds have their special features, which are defined in the pension plan. According to what is defined, pension plans can generally be divided into defined benefit (DB) pension plans and defined contribution (DC) pension plans (Reilly and Norton 1999, p.66). A defined benefit (DB) pension plan promises to pay retirees a specific income stream after retirement. A defined contribution (DC) pension plan is a plan where the minimum contributions by the plan sponsor, or the plan member, or both, are fixed as part of the plan's rules/contract (Yermo 2001, p. 4). The plan does not promise set benefits. The plan's risk is borne by the employees. Some DC pension plans may have additional promises. DC plans with promises are plans where the plan sponsor, provider or administrator offers some form of insurance against financial and/or longevity risk. A DC plan with a guaranteed return is the main type of defined contribution plan with promises.

Whatever the type of pension plan, it should also include the pension plan's anticipated investment policy. In Slovenia, for example, a regulation in December 2006 was accepted that demands a more accurate determination of the Statement of Investment Policy and 
the methods of risk measurement and management implemented by the pension fund's manager (Uradni list RS 2006b, p. 15455). The statement should include investment objectives and policy, fundamental and additional restrictions on investments, a benchmark for the measurement of portfolio performance, investment management techniques and methods of risk measurement and management.

Regarding investment objectives, the following two are possible, i.e. capital preservation and capital appreciation (Reilly and Norton 1999, p. 45-47). Capital preservation means that the investors want to minimize their risk of loss, usually in real terms. They seek to maintain the purchasing power of their investment. Generally, this is a strategy for strong risk-averse investors. Capital appreciation is an aggressive strategy for investors who are willing to take on risks in order to meet their objectives. Under this strategy, growth primarily occurs through capital gains. Since pension funds in Slovenia are required to promise a minimum guaranteed return, a capital preservation strategy is usually selected.

\subsection{Risks pension funds are exposed to with an emphasis on investment risks}

For pension fund managers, identifying and managing risks is key to their stable operation and functioning. Even pension funds are exposed to different kinds of financial risks, and here more attention is directed primarily toward investment risks. Regarding investment risks, the following key types should be taken into consideration: market risk or interest-rate risk, reinvestment risk, credit risk or default risk, marketability risk or liquidity risk and exchange rate risk (Fabozzi 2000, p. 5).

Market risk or interest-rate risk (sometimes also called the price risk) is the risk of the debt security's price changing as a result of a change in the general level of interest rates or a change in the interest rates of specific securities. For an investor who potentially has to sell a security before its maturity date, an increase in interest rates will mean the realization of a capital loss.

It is possible for an investor to manage interest rate risk with the proper accounting treatment of an investment. With respect to the financial reporting of assets, there are three possible methods: (1) market value, (2) amortized cost or historical cost, and (3) the lowering of cost or market value (LCM). In the market value method, an investment is valued at its market value. It is said to be "marked to market". In the amortized cost method, the value reflects an adjustment of the acquisition cost for debt securities purchased at a discount or premium from their maturity value (Fabozzi 2000 , p. 452). This method is sometimes referred to as "book value accounting." It is important to note that real cash flow is the same regardless of accounting treatment, but there can be substantial differences in financial statements using these three methods.

Reinvestment risk is the risk that the interest rate, at which interim cash flows can be reinvested (reinvestment rate), will fall. It is assumed that the cash flows received from a debt security are reinvested. The additional income from such a reinvestment, sometimes called interest-on-interest, depends on the prevailing interestrate levels at the time of reinvestment, as well as on the reinvestment strategy. Reinvestment risk is greater for longer holding periods, as well as for debt securities with large, early, cash flows, such as high-coupon bonds. It should be noted that interest-rate risks and reinvestment risks have offsetting effects. That is, the interest-rate risk is the risk that interest rates will rise, thereby reducing the security's price. In contrast, the reinvestment risk is the risk that interest rates will fall, thereby reducing additional revenue from interest-on-interest (Fabozzi 2000 , p. 6). With the precise matching of the duration of assets and liabilities, both risks can be offset.

Marketability risk, or liquidity risk, is defined as the uncertainty introduced by the secondary market for an investment. The investor expects to be able to convert the security into cash and use the proceeds for current consumption or another investment. The more difficult it is to make this conversion, the greater the liquidity risk (Reilly and Norton 1999, p. 20). Some authors (Holmes 2002 , p. 84) relate liquidity risk more generally to the ability (or inability) to buy or sell securities at short notice at a fair or good price. The primary measure for the marketability or liquidity is the size of the spread between the bid price (the price at which a security can be sold) and the ask price (the price at which a security can be purchased) as quoted by a dealer. The greater the dealer spread, the greater the liquidity risk (Fabozzi 2000, p. 8).

Credit risk or default risk refers to the risk that the issuer of a security may default, and the exchange rate risk or currency exchange risk is the risk associated with the value of foreign currency holdings caused by fluctuations in currency markets. The likelihood of 
incurring this risk rises as investors buy and sell assets around the world.

Managing all types of risks demands prudent action by pension fund managers in order for them to meet their obligations. As governments are also interested in including as many employees in supplementary pension schemes as possible (the condition for this is also adequate protection of the insured individual) efforts to unify the pension fund market and investment legislation as well as introduce adequate risk measurement and management methods have been stepped up also at the international level (i.e., the European Commission and the OECD) in the past decade. In this regard, the asset-liability management (ALM) of pension funds has also become increasingly important.

\subsection{Portfolio management and the ALM strategy}

A basic assumption of portfolio theory is that an investor wants to maximize the returns from his investments for a given level of risk, while simultaneously considering all the assets and liabilities and connections between them. The creation of an optimum investment portfolio is not simply a matter of combining a lot of unique individual securities that have desirable riskreturn characteristics; the relationship between them should also be considered as the returns from all these investments interact (Reilly and Norton 1999, p. 189).

Both the asset and liability side of the pension fund balance sheet can contribute to the risk. On the asset side, risks can involve both asset-liability mismatching (where assets are not adequately structured to meet benefits when they become due) and return related risks (where insufficient income is generated to cover liabilities) (OECD 2007, p. 3). An institutional investor is concerned with both the amount and timing of liabilities, because its assets must produce cash flow to meet any payments it has promised to make in a timely way.

Portfolio management, when considering assets and liabilities, offers the following alternative approaches to asset allocation: immunization, cash-flow matching, shortfall risk management and asset-liability management (Davis 2001b, p. 5).

With immunization, the investor tries to stabilize the value of the investment at the end of the holding period, i.e. to hold an entirely riskless position. This is typically done, in light of the interest rate risk, by appropriately adjusting the duration of the assets held to that of the liabilities. It necessitates a constant rebalancing of the portfolio, as well as the existence of assets that have a similar duration as that of liabilities (Davis 2001b, p. 5). Portfolio immunization attempts to balance two components of interest rate risk, i.e. price risk and reinvestment risk. The price risk and the reinvestments caused by a change in interest rates have opposite effects on ending-wealth position (Reilly and Norton 1999, p. 709). An increase in interest rates will cause an ending price below expectations (if the bond is sold before maturity), but the reinvestment rate for interim cash flows will be above expectations. A decline in market interest rates will cause the reverse situation. In an immunized portfolio, whether market rates rise or fall, the value of the portfolio at the end of the time horizon should be close to its target value.

Using cash-flow matching strategy, pension fund managers attempt to immunize their balance sheets by matching the projected payments of pension benefits with cash-flow generated by investments (Laboul 2006, p. 8). One way institutions can meet their liabilities is to construct a portfolio of assets - usually bonds - that generate cash flows matching liability cash flows. Most institutions have rejected this approach because it generally eliminates the opportunity to generate excess returns. Instead, they have established a return target for their assets and then invest in a mix of stocks, bonds and other asset classes with the goal of meeting or beating that return target. With this approach, also known as the asset-driven approach, success is measured by how well the portfolio's investments perform versus market benchmarks (Pacific Investment Management Company 2007, p. 1-3).

Shortfall risk management (or portfolio insurance) approaches put particular stress on avoiding downward moves in the context of minimum solvency levels for pension funds. Shortfall risk sees the investor as maximizing the return of the portfolio subject to a ceiling on the probability of incurring a loss (e.g. by shifting from equities to bonds as the minimum desired value is approached). Through such means, the value of a portfolio may be prevented from falling below a given value, such as that defined by the value of a guaranteed return, defined benefits, or the minimum funding level of a pension fund (Davis 2001b, p. 5).

Asset-Liability-Management (ALM) is an investment technique wherein the long term balance between assets and liabilities is maintained by the choice of a portfolio of assets with similar return, risk and duration characteristics to liabilities. The characteristics of an individual asset may 
differ from those of the liabilities, but at the portfolio level they should be matched (Davis 2002, p. 6). It can be defined as the ongoing process of formulating, implementing, monitoring, and revising strategies related to assets and liabilities in an attempt to achieve financial objectives for a given set of risk tolerances and constraint. ALM is relevant to, and critical for, the sound management of the finances of any institution that invests to meet liabilities (Hess 2000, p. 6).

Liability-driven investing shifts the focus of asset allocation back to the real purpose of the assets, which is to meet liabilities. Thus, the defining element of a liabilitydriven investment approach is that portfolio performance is benchmarked against the institution's liabilities, rather than a benchmark with no direct relation to the liabilities. This is also how the strategy got its name. It is a flexible strategy, so portfolios can take many different forms depending on the institution's desire for excess returns and tolerance for risk (Pacific Investment Management Company 2007, p. 1-2). In order to select the right investments we first have to know the characteristics of the liabilities.

No two institution's liabilities are the same, but virtually all liabilities have one characteristic in common: falling interest rates cause liabilities to increase, while rising rates cause liabilities to decline ${ }^{1}$. Therefore, falling interest rates may be the single largest risk that institutions face in relation to their liabilities (Pacific Investment Management Company 2007, p. 2). To hedge this risk, many institutions implementing a liability-driven approach turn to bonds. Bonds typically appreciate in value when interest rates decline, and therefore tend to be among the most common ingredients in a liabilitydriven portfolio. A second common characteristic is that most liabilities are long-term. The longer-term the liabilities are, the more sensitive they are to changes in interest rates. For example, a drop in interest rates will cause liabilities owed 30 years in the future to increase more than liabilities owed 10 years in the future. Similarly, longer-term bonds are also more sensitive to changes in interest rates. Therefore, another common element in liability-driven investing is that bonds held in the portfolio tend to be long-term bonds. Aside from the common use of long-term bonds, liability-driven portfolios can vary significantly from institution to institution. Some institutions, for example, can have

\footnotetext{
1 The market value is the present value of future liabilities, discounted at a proper interest rate. When interest rates rise, the present (or the market) value falls (Fabozzi 2000, p. 451).
}

liabilities that are sensitive to inflation and may employ inflation-linked bonds to hedge inflation risk. Other institutions may have a higher tolerance for volatility in the portfolio relative to liabilities, and may therefore employ alternative asset classes.

Pension fund investment and risk management practices have often focused more on asset returns instead of the actual liability structure of the pension balance sheet. In part, this is because assets are more easily adjusted in the short term to meet changing circumstances than pension liabilities. In practice, many pension funds have pursued investment strategies measured relative to broad market indices (OECD 2005, p. $36,71)$.

Several factors drive institutions towards liabilitydriven investing. The most significant of these factors is probably the fact that asset-driven strategies left many pension plans and other institutions with deficits relative to their liabilities after 2001 and 2002, when the shocks on the stock exchange due to events connected with September 11 in the U.S. severely reduced numerous pension funds' available resources for covering liabilities. Shortfall in assets relative to liabilities forced pension fund managers to cover the difference from their own capital. ${ }^{2}$ As data shows, the pension funds' projected benefit obligation (PBO) funding declined globally in 2001 and 2002 due to a combination of falling interest rates and modest or negative equity returns. The euro zone PBO funding ratio went from more than $120 \%$ at the beginning of 2001 to less than $80 \%{ }^{3}$ in just two years. The U.S. and U.K. experienced a similar shift from surplus to deficit during the same period. The PBO ratio of Japanese pension funds was already below 60\% in 2003 (Pacific Investment Management Company 2007, p. 2).

Pension funding ratios have improved in subsequent years as a result of the combination of rising interest rates and higher equity market returns, though even more as the result of the sound management of pension funds assets as well as taking more into account the characteristics of pension fund liabilities. Those pension funds that did not adapt their investment strategy were hit again by the appearance of the global financial crisis in 2008. 
As noted by Davis (2001a, p. 7) minimum funding levels and limits on overfunding provide tolerance limits to the variation of assets around the value of liabilities. If the assets are selected in such a way that their risk, return and duration characteristics match those of liabilities, there is a "liability immunizing portfolio". This protects the portfolio against risks of variation in interest rates, real earnings growth and inflation in pension liabilities.

\section{The Data and Empirıcal Analysıs}

A practical example of a pension fund investment policy taking into account the requirement to achieve the minimum guaranteed return and managing risk using the asset-liability management (ALM) strategy is presented and analyzed here. Because pension fund managers in Slovenia usually do not disclose their data to the public, a combination of publicly accessible data from two Slovenian pension funds is used; other data are hypothetical or invented. The number and structure of insured individuals is taken from the Capital Mutual Pension Fund (Kapitalski vzajemni pokojninski sklad; managed by Kapitalska družba; 2010 data), and the data on the investment and liabilities structure is taken from the insurance fund of the pension investment company Moja naložba (2012 data).

The effect of the risk of abnormal events on the portfolio will be verified using stress tests (i.e., sensitivity and scenario tests). The majority of investment risks that the manager is exposed to while managing the portfolio will be defined; in addition, suitable methods of measuring these risks will be identified and suggestions for their management will be presented.

The process of asset-liability management will be based on a synthetic defined contribution (DC) pension fund with 130 million EUR of assets and 36,000 pension plan members. Assets and liabilities will be matched through risk, return and duration characteristics. As previously indicated, asset-liability management helps the manager hedge, or at least limit, the negative impact of financial risks that they are exposed to when managing a pension fund.

In the first step, we estimated the average duration of a pension fund's liabilities while considering the pension plan members' structure. A more accurate calculation of duration can be prepared by actuaries, based on different mathematical assumptions: members' age and gender structure, mortality tables, projected returns, selected discount rates, pension benefits promised, the probability of exiting pension insurance or switching to another pension plan, etc. To simplify the calculation of the average duration, the following assumptions can be stated:

- the number of pension plan members structured by age and gender is sufficient to calculate the duration of liabilities (other parameters can be disregarded),

- the distribution of pension plan members within an individual age group is even,

- retired pension plan members will receive pension benefits in a lump-sum (instead of a monthly annuity).

\begin{tabular}{|c|c|c|c|c|c|}
\hline \multirow[b]{2}{*}{$\begin{array}{l}\text { Age group } \\
\text { (in years) }\end{array}$} & \multirow[b]{2}{*}{$\begin{array}{l}\text { Average } \\
\text { (in years) }\end{array}$} & \multicolumn{2}{|c|}{ Female members } & \multicolumn{2}{|c|}{ Male members } \\
\hline & & Number & $\begin{array}{l}\text { Assets } \\
\text { (in EUR) }\end{array}$ & Number & $\begin{array}{l}\text { Assets } \\
\text { (in EUR) }\end{array}$ \\
\hline from 11 to 20 & 15 & 0 & 0.00 & 18 & $9,646.75$ \\
\hline from 21 to 30 & 25 & 930 & $1,036,662.22$ & 1,774 & $2,481,977.42$ \\
\hline from 31 to 40 & 35 & 3,622 & $10,802,364.17$ & 5,799 & $20,529,246.93$ \\
\hline from 41 to 50 & 45 & 4,949 & $17,166,278.09$ & 8,037 & $36,378,284.56$ \\
\hline from 51 to 60 & 55 & 3,430 & $11,637,980.78$ & 5,918 & $24,291,070.08$ \\
\hline from 61 to 70 & 65 & 283 & $808,091.34$ & 1,230 & $4,805,251.43$ \\
\hline from 71 to 80 & 75 & 0 & 0.00 & 10 & $53,146.23$ \\
\hline & Sum & 13,214 & $41,451,376.60$ & 22,786 & $88,548,623.40$ \\
\hline
\end{tabular}

Table 1: Age and gender distribution of pension plan members

Data source: Kapitalska družba (2011, p. 14)

\begin{tabular}{|lccc|}
\hline & Females & Males & Average \\
\hline Average age & 45.09 years & 45.96 years & \\
Retirement age & 63.00 years & 65.00 years & \\
\hline Duration of liabilities & 17.91 years & 19.04 years & \\
\hline
\end{tabular}

Table 2: Calculation of average liabilities duration (weighted by assets)

Source: own calculations 
The average age of pension plan members can be calculated using the following equation:

$$
\overline{A G E}=\frac{1}{A} * \sum_{i=1}^{7}\left(\text { age }_{i} * a_{i}\right)
$$

where:

$\overline{A G E}=$ average age of pension plan members (in years), $A=$ sum of pension fund's assets (in EUR), age $e_{i}=$ average age at group $i$ (in years), $a_{i}=$ assets at group $i$ (in EUR).

Using the information about the pension plan members' age, gender and the sum of assets saved, we were able to calculate that the average plan member will retire and exit the pension plan after 18.68 years.

If we are to match the duration of assets to duration of pension liabilities, we have to select investments with similar interest rate sensitivity as that of liabilities. Most of the funds were invested in long-term government and corporate bonds. It is also possible to invest a part of assets in shares and mutual funds, as they are considered to have no maturity. By precisely matching the duration of assets to the duration of liabilities, interest-rate risk and reinvestment risk get perfectly hedged. The manager of the fund can also afford a smaller deviation from a perfect match with the intent of earning higher returns. The pension fund would then be more vulnerable to financial risks.

The second step has been to match assets and liabilities from the required return point of view. The pension fund's liabilities can be divided into three components:

- net premiums received (sum of gross premiums received, net of the front-end fee),

- guaranteed return earned (minimum guaranteed return added to net premiums received, as promised by the manager in the pension fund's plan),

- a return above the guarantee or provisions (the positive difference between actual returns earned and guaranteed returns promised ${ }^{4}$ ).

\footnotetext{
4 In Slovenia, the process of creating and drawing provisions is explained in greater detail in the Pension and Disability Insurance Act (Uradni list Republike Slovenije 2006a, p. 11133-11134).
}

We supposed for our pension fund that the minimum guaranteed return promised by the pension plan is $60 \%$ of the average annual return on Slovenian government securities with a term to maturity above one year. For the year 2012 , this is $2.30 \%$. The management fee is $1.20 \%$ p.a., deducted from the pension fund's return. The minimum guaranteed return is added only to net premiums received, increased by the guaranteed return already earned. The manager of the pension fund does not promise a guaranteed return on provisions (return in excess of the guarantee). Should a pension fund's assets fall below the guaranteed value (sum of net premiums received and the guaranteed return already earned), the manager is not allowed to charge his management fee. Until the provisions are formed again, the manager's goal should be to earn a return, above the guaranteed return, for at least the amount of the management fee.

\begin{tabular}{|l|cc|c|}
\hline Liability & $\begin{array}{c}\text { Min. } \\
\text { guarantee } \\
\text { d return }\end{array}$ & $\begin{array}{c}\text { Management } \\
\text { fee }\end{array}$ & $\begin{array}{c}\text { Required } \\
\text { rate of } \\
\text { return }\end{array}$ \\
\hline $\begin{array}{l}\text { Provisions } \\
\text { Guaranteed } \\
\text { return }\end{array}$ & - & - & - \\
$\begin{array}{l}\text { Net } \\
\text { premiums } \\
\text { received }\end{array}$ & $2.30 \%$ & $1.20 \%$ & $3.50 \%$ \\
\hline
\end{tabular}

Table 3: Pension fund's liabilities structure and the required rate of return

\section{Source: own calculations}

Before we select the investments that are to be matched to our pension liabilities, we have to structure the fund's liabilities from a risk point of view. Let us keep our liabilities structured to net premium received, a guaranteed return and provisions formed. Asset-liability management can also be called surplus management (see Fabozzi 2000, p. 450). It is actually a tradeoff between managing shortfall risk and taking an acceptable risk to earn a sufficient return on the assets invested.

\begin{tabular}{|lcc|}
\hline Liability & Share & Risk allowed \\
\hline $\begin{array}{l}\text { Provisions } \\
\text { Guaranteed }\end{array}$ & $5.00 \%$ & High \\
$\begin{array}{l}\text { return } \\
\text { Net premiums } \\
\text { received }\end{array}$ & $9.00 \%$ & Moderate \\
\hline
\end{tabular}

Table 4: Pension fund's liabilities structure and risk Source: own calculations 


\begin{tabular}{|lrr|rrr|}
\hline Assets & \multicolumn{1}{c|}{ Value } & Share & \multicolumn{1}{c|}{ Share } & \multicolumn{1}{c|}{ Value } & Liabilities \\
\hline Other currencies (USD, GBP) & $6,500,000.00$ & $5.00 \%$ & $5.00 \%$ & $6,500,000.00$ & Technical provisions \\
Local currency (EUR) & $123,500,000.00$ & $95.00 \%$ & $9.00 \%$ & $11,700,000.00$ & $\begin{array}{r}\text { Guaranteed return } \\
\end{array}$ \\
& & & $86.00 \%$ & $111,800,000.00$ & Net premiums received \\
\hline Total & $130,000,000.00$ & $100.00 \%$ & $100.00 \%$ & $130,000,000.00$ & \\
\hline
\end{tabular}

Table 5: Currency structure of assets and liabilities

Source: own calculations

\begin{tabular}{|c|c|c|c|c|c|c|c|c|}
\hline Assets & Duration & Return & Share & Risk & Share & Return & Duration & Liabilities \\
\hline Shares & - & - & $5.00 \%$ & High & $5.00 \%$ & - & & Technical provisions \\
\hline Mutual funds & - & - & $9.00 \%$ & Moderate & $9.00 \%$ & $2.30 \%$ & & Guaranteed return \\
\hline Liquidity reserve & 0.01 & $3.00 \%$ & $11.00 \%$ & \multirow{3}{*}{ Low } & \multirow{3}{*}{$86.00 \%$} & \multirow{3}{*}{$2.30 \%$} & & \multirow{3}{*}{ Net premiums received } \\
\hline Bonds - corporate & 3.85 & $5.30 \%$ & $35.00 \%$ & & & & & \\
\hline $\begin{array}{l}\text { Bonds - } \\
\text { government }\end{array}$ & 6.02 & $4.50 \%$ & $40.00 \%$ & & & & & \\
\hline Average & 4.37 & $4.63 \%$ & $100.00 \%$ & & $100.00 \%$ & $2.30 \%$ & 18.68 & Average \\
\hline
\end{tabular}

Table 6: Risk, return and duration structure of assets and liabilities

Source: own calculations

\begin{tabular}{|lccc|}
\hline Investment & Average yield & Average duration & Modified duration \\
\hline Liquidity reserve & $3.00 \%$ & 0.01 & 0.01 \\
Bonds - corporate & $5.30 \%$ & 3.85 & 3.66 \\
Bonds - government & $4.50 \%$ & 6.02 & 5.76 \\
\hline Average & $4.63 \%$ & 4.37 & 4.18 \\
\hline
\end{tabular}

Table 7: Debt securities structure with duration and return ratios Source: own calculations

For every gross premium received, only front-end fees can be charged by the manager. The net premium will then fall into the net premiums received category. As this category may never drop below the sum of all premiums paid to the fund, the manager can only afford a minimum risk. At the end of every month, the guaranteed return is calculated on net premiums received, as a percentage, as promised in the pension plan. If the actual return falls below the guaranteed return, provisions may be used by the manager of the fund to cover the difference. It is possible that the actual return falls below 0 within a certain period. For the amount of the guaranteed return earned, the manager is allowed to take moderate risks. Because there is no guaranteed return promised on a pension fund's provisions, the manager can be allowed to expose this share of the pension fund's liabilities to maximum risk. But he or she must keep in mind not to let the fund's provisions fall below 0 . This would be the case if the actual return would fall below the guaranteed return, and the provisions would not be sufficient to cover the deficit. The manager would then have to form additional provisions from his or her own capital.

To estimate how unfavourable events affect a pension fund's capitalization, stress tests can be performed. In our case, we used two fundamental techniques. To study the impact of exchange rate risk and stock exchange decline on a pension fund's portfolio return, sensitivity tests were used. Since the impact of interest-rate risk is more difficult to comprehend, a scenario test was used with the minimum guaranteed return as the key financial driver. In the following tables, we have summarized the characteristics of the pension fund's liabilities as defined in the beginning of this chapter. The characteristics of a pension fund's assets are hypothetical and not precisely matched to liabilities. Stress tests help us understand how a mismatch between assets and liabilities can affect the return. To simplify the case we assumed that there are no new premiums paid to the pension fund during the observation period. In our asset-liability management case, currency risk, price risk and interest-rate risk were put into focus.

Stress Test I.: a $-10 \%$ decline of a basket of foreign currencies against the EUR

Euro-denominated investments represent $95 \%$ of a pension fund's assets. The other $5 \%$ is invested into securities, denominated in currencies, like USD, GBP or JPY. For Euro-denominated investments we will assume an average annual return of $4.67 \%$. 


\begin{tabular}{|c|c|c|c|}
\hline Assets & $\begin{array}{c}\text { Value } \\
\text { (t) }\end{array}$ & $\begin{array}{c}\text { Return } \\
\text { (in \%) }\end{array}$ & $\begin{array}{l}\text { Value } \\
(t+1)\end{array}$ \\
\hline Other currencies (USD, GBP, JPY) & $6,500,000.00$ & $-10.00 \%$ & $5,850,000.00$ \\
\hline Local currency (EUR) & $123,500,000.00$ & $4.67 \%$ & $129,265,500.00$ \\
\hline Total & $130,000,000.00$ & $3.94 \%$ & $135,115,500.00$ \\
\hline
\end{tabular}

Table 8: Impact of a decline of foreign currencies on the portfolio (in euros)

Source: own calculations

\begin{tabular}{|lrrr|}
\hline Assets & \multicolumn{1}{c|}{$\begin{array}{c}\text { Value } \\
\text { (t) }\end{array}$} & \multicolumn{1}{c|}{$\begin{array}{c}\text { Value } \\
\text { (in \%) }\end{array}$} & \multicolumn{1}{c|}{ (t + 1) } \\
\hline Stocks & $6,500,000.00$ & $-20.00 \%$ & $5,200,000.00$ \\
Mutual funds & $11,700,000.00$ & $-15.00 \%$ & $9,945,000.00$ \\
\hline Liquidity reserve & $14,300,000.00$ & $3.00 \%$ & $14,729,000.00$ \\
Bonds- corporate & $45,500,000.00$ & $5.30 \%$ & $47,911,500.00$ \\
Bonds-government & $52,000,000.00$ & $4.50 \%$ & $54,340,000.00$ \\
\hline Total & $130,000,000.00$ & $1.64 \%$ & $132,125,500.00$ \\
\hline
\end{tabular}

Table 9: Impact of stock market decline on the portfolio (in EUR)

Source: own calculations

\begin{tabular}{|lrrr|}
\hline Liabilities & \multicolumn{1}{c|}{$\begin{array}{c}\text { Value } \\
\text { (t) }\end{array}$} & $\begin{array}{c}\text { Return } \\
\text { (in \%) }\end{array}$ & \multicolumn{1}{c|}{$\begin{array}{r}\text { Value } \\
\text { (t + 1) }\end{array}$} \\
\hline Technical provisions & $6,500,000.00$ & - & $4,212,247.00$ \\
Guaranteed return & $11,700,000.00$ & $2.30 \%$ & $14,540,500.00$ \\
Net premiums received & $11,800,000.00$ & $2.30 \%$ & $11,800,000.00$ \\
\hline Total & $130,000,000.00$ & $0.44 \%$ & $130,552,747.00$ \\
Management fee & 0.00 & $1.20 \%$ & $1,572,753.00$ \\
Guaranteed value of the fund & $123,500,000.00$ & $2.30 \%$ & $126,340,500.00$ \\
\hline
\end{tabular}

Table 10: Impact of stock market decline on a fund's liabilities (in EUR)

Source: own calculations

As shown in Table 8, a $-10 \%$ decline of investments, denominated in other currencies, would lead to a 650,000.00 EUR loss. On the other hand, securities, denominated in Euros, would yield 5,765,500.00 EUR of positive return. Together, the pension fund's assets would rise by $5,115,500.00$ EUR or $3.94 \%$. As calculated in Table 3 , the required return on a pension fund's liabilities is $3.50 \%$. With the return actually earned, the pension fund's manager is able to cover the minimum guaranteed return and charge a $1.20 \%$ management fee. An additional return of $0.44 \%$ (3.94\% - 3.50\%) would increase the fund's technical provisions. Since the share of the fund's investments in foreign currencies is small, the exchange rate risk is not that important. The manager can afford small currency mismatches between assets and liabilities to increase the diversification of the fund's assets, and therefore decrease the price risk, which represents a much greater threat.
Stress Test II.: a -20\% decline in the stock market

Our pension fund is exposed to equity directly and indirectly with the investments in mutual funds. Because the mutual funds can also diversify their assets in the investment with less risk (bonds, treasury bills or bank deposits), we assumed that their decline could only reach $75 \%$ of the stock market decline. We also assumed that the volatility of the stock market had no effect on the bond market. Our focus remained on the impact of the stock market decline with other factors constant.

A $-20 \%$ decline in stock prices would represent a capital loss of $-1,300,000.00$ EUR, and a $-15 \%(20 \% \times 0.75)$ decline in mutual funds would mean another $1,755,000.00$ EUR negative return to the pension fund. Other investments would add 5,180,500.00 EUR of positive return. In total, the pension fund's assets would increase by $2,125,500.00$ EUR or $1.64 \%$.

The guaranteed value of the fund is the sum of net premiums received and the guaranteed returns already earned. At the end of the year, the pension fund's manager must be able to increase the guaranteed value of the fund by at least the guaranteed return, which is $2.30 \%$. As the net premiums received can only be 


\begin{tabular}{|lrcrr|}
\hline Scenario & & $\begin{array}{c}\text { Fund's value } \\
(\mathbf{t}+\mathbf{1})\end{array}$ & $\begin{array}{c}\text { Tech. provisions } \\
(\mathbf{t}+\mathbf{1})\end{array}$ & \multicolumn{1}{c|}{$\begin{array}{c}\text { Management fee } \\
(\mathbf{t}+\mathbf{1})\end{array}$} \\
\hline \% decrease: & $-4.93 \%$ & $132,840,500.00$ & $6,500,000.00$ & $1,586,562.37$ \\
\% decrease: & $-20.00 \%$ & $130,552,747.00$ & $4,212,247.00$ & $1,572,753.00$ \\
\% decrease: & $-57.87 \%$ & $126,340,500.00$ & 0.00 & 0.00 \\
\hline
\end{tabular}

Table 11: Impact of stock market decline on management fee and provisions (in EUR)

Source: own calculations

increased by new premiums paid to the fund, the sum will be added only to the guaranteed returns already earned. Because the pension fund's assets are still above the guaranteed value, the manager is allowed to charge the fund for the management fee, which is deducted from technical provisions. The management fee is calculated as $1.20 \%$ of the average pension fund's value. The pension fund's net return, following the deduction of the management fee, is $0.44 \%(1.64 \%-1.20 \%)$.

Should the negative trend in the stock market continue and the manager already decrease the technical provisions to 0 , the difference between the actual return and the minimum guaranteed return would have to be covered by his own capital. He would also lose the right to charge his management fee. Using "goal seek" in our model, it is possible to calculate the maximum percentage of the stock market decline, where the manager would still be entitled to charge the management fee without decreasing technical provisions or the percentage at which he would lose all technical provisions.

If the stock market declined by $-4.93 \%$ (and therefore mutual funds by $-3.70 \%$ ), the return on other investments would still be sufficient to cover both the guaranteed return and the management fee. Technical provisions would remain intact. On the contrary, in the case of a $57.87 \%$ decline in stock prices (and a $-43.40 \%$ decline in mutual funds), the manager would lose all technical provisions and earn no management fee. The pension fund's value at the end of the year would only be equal to the guaranteed value of the fund. Any further decline in the pension fund's investments would require the manager to cover the loss from his own capital. To avoid such a risk, he would have to adjust the structure of investments to a new structure of liabilities. The share of equity investments should be reduced to match the level of technical provisions. If a pension fund's technical provisions are reduced to 0 , it would be prudent to reduce equity investments to 0 as well. Their share can be increased again, when the actual returns exceed the guaranteed return.
Stress Test III.: A 100-Basis Point Increase Across the Yield Curve

The most important risk that the pension fund manager is exposed to is interest rate risk. We tested the scenario of an increase across the yield curve by 100 basis points. At the same time, we assumed that the yield curve was flat and that there was a parallel shift upward on all durations at the beginning of the observation. Until the end of the year, the yield curve remains unchanged. The influence of the stock market was disregarded. We used the information about debt security diversification, duration and return ratios from Table 7. But before we discuss the stress test results, let us explain how the ratios were calculated and how to interpret them. The price (market value) of a bond at a new required return was calculated using the following equation (Reilly and Norton 1999, p. 567):

$$
P=\sum_{t=1}^{n} \frac{C_{t}}{(1+y)^{t}}+\frac{M}{(1+y)^{n}}
$$

where:

$P=$ price of $a$ bond, $y=$ interest rate (required annual yield), $C_{t}=$ coupon payment in year $t, M=$ maturity value, $n$ $=$ number of years to maturity (term to maturity).

As shown by the equation, the price of a bond equals the present value of the cash flows, discounted at the required annual yield. The price of a bond changes inversely with the change in the required yield. As the required yield increases (decreases), the present value of the cash flows decreases (increases). However, the relationship is not linear. For a given change in basis points, the percentage price increase is greater than the percentage price decrease (Fabozzi 2000, p. 23).

The volatility of a bond's price is dependent on its maturity. With all other factors remaining constant, the longer the maturity of a bond, the greater the price volatility resulting from a change in market yields. 


\begin{tabular}{|lcccc|}
\hline \multicolumn{1}{|c}{ Assets } & $\begin{array}{l}\text { Value } \\
\text { (t) }\end{array}$ & $\begin{array}{c}\text { Coupon } \\
\text { (in \%) }\end{array}$ & $\begin{array}{c}\text { New } \\
\text { yield }\end{array}$ & Coupon payments \\
\hline Shares & $6,500,000.00$ & - & - & - \\
Mutual funds & $11,700,000.00$ & - & - & - \\
\hline Liquidity reserve & $14,300,000.00$ & $3.00 \%$ & $4.00 \%$ & - \\
Bonds- corporate & $45,500,000.00$ & $5.30 \%$ & $6.30 \%$ & semiannual \\
Bonds-government & $52,000,000.00$ & $4.50 \%$ & $5.50 \%$ & annual \\
\hline Total & $130,000,000.00$ & $4.63 \%$ & $5.63 \%$ & \\
\hline
\end{tabular}

Table 12: Investment portfolio at the beginning of the investment horizon (in EUR)

Source: own calculations

\begin{tabular}{|c|c|c|c|c|}
\hline Assets & Coupon payment & $\begin{array}{l}\text { Interest-on- } \\
\text { interest }\end{array}$ & Market value & Sum \\
\hline Shares & - & - & - & $6,500,000.00$ \\
\hline Mutual funds & - & - & - & $11,700,000.00$ \\
\hline Liquidity reserve & $429,000.00$ & 0.00 & $14,300,000.00$ & $14,729,000.00$ \\
\hline Bonds-corporate & $2,411,500.00$ & $37,981.13$ & $43,912,050.00$ & $46,361,531.13$ \\
\hline Bonds - government & $2,340,000.00$ & 0.00 & $49,400,000.00$ & $51,740,000.00$ \\
\hline Total & $5,180,500.00$ & $37,981.13$ & $107,612,050.00$ & $131,030,531.13$ \\
\hline Guaranteed value & & & & $126,958,000.00$ \\
\hline
\end{tabular}

Table 13: Impact of an interest rate increase on investment portfolio (in EUR)

Source: own calculations

The duration of a bond is a more appropriate measure for time characteristics than the term to maturity, because it considers both the repayment of capital at maturity, and the size and timing of coupon payments prior to final maturity. Duration is defined as the weighted average time to full recovery of principal and interest payments (Reilly and Norton 1999, p. 587-588):

$$
\operatorname{Dur}(\text { in years })=\frac{\sum_{t=1}^{n} \frac{t \times C_{t}}{(1+y)^{t}}+\frac{n \times M}{(1+y)^{n}}}{P}
$$

where:

Dur $=$ duration, $C_{t}=$ interest payment that occurs in period $t, M=$ maturity value, $P=$ bond price, $t=$ time period in which the payment occurs $(t=1, \ldots, n), n=$ number of time periods to maturity, $y=$ yield to maturity.

Modified duration is a measure of the sensitivity of a bond's price to interest-rate changes, assuming that the expected cash flow does not change with interest rates. It can be used as a measure of interest-rate risks. The modified duration shows the approximated change of a bond's, or a bond portfolio's, market value when the interest rates change. It can be calculated using the equation (Fabozzi 2000, p. 360):

$$
D u r_{m o d}=\frac{D u r}{(1+y)}
$$

where:

Dur ${ }_{\text {mod }}=$ modified duration, Dur $=$ duration, $y=$ yield to maturity.

An investor who purchases a bond can expect to receive a return from one or more of these sources: the periodic coupon interest payments made by the issuer, any capital gains (or capital losses) when the bond either matures, is called, or is sold, and interest income generated from reinvestment of the periodic cash flows (interest-on-interest). If an investor has received coupon payments prior to the bond's maturitity, they should be reinvested in order to earn additional income. Intereston-interest can be calculated using the equation for the future value of an ordinary annuity (an ordinary annuity involves the (re)investment of equal sums at equal intervals at an equal interest rate) (Fabozzi 2000, p.14,44):

$$
P_{n}=A\left[\frac{(1+r)^{n}-1}{r}\right] \text {, }
$$

where:

$P_{n}=$ interest on interest, $A=$ amount of the annuity, $r=$ rate of return, $n=$ number of years to maturity.

The reason we are using this equation is that we are reinvesting fixed periodical coupon payments at a fixed rate of return. The future value can then be calculated using the expected reinvestment rate of return. The data calculated from these equations are summarized in Table 12 and 13. The key financial driver fort4tress testing is the 


\begin{tabular}{|lrrr|}
\hline \multicolumn{1}{|c}{ Liabilities } & Value & \multicolumn{1}{c|}{$\begin{array}{r}\text { Return } \\
\text { (in \%) }\end{array}$} & \multicolumn{1}{c|}{$\begin{array}{r}\text { Value } \\
\text { (t + 1) }\end{array}$} \\
\hline Technical provisions & \multicolumn{1}{c}{ (t) } & - & $2,506,347.94$ \\
Guaranteed return earned & $11,700,000.00$ & $2.80 \%$ & $15,158,000.00$ \\
Net premiums received & $111,800,000.00$ & $2.80 \%$ & $111,800,000.00$ \\
Management fee & 0.00 & $1.20 \%$ & $1,566,183.19$ \\
\hline Total & $130,000,000.00$ & $0.79 \%$ & $131,030,531.13$ \\
Guaranteed Value of the Fund & $123,500,000.00$ & $2.80 \%$ & $126,958,000.00$ \\
\hline
\end{tabular}

Table 14: Impact of an upward shift of the yield curve on pension liabilities (in EUR)

Source: own calculations

\begin{tabular}{|cccccc|}
\hline Date of issue & Maturity date & Coupon & $\begin{array}{c}\text { Value } \\
\text { (in EUR) }\end{array}$ & Duration & $\begin{array}{c}\text { Modified } \\
\text { duration }\end{array}$ \\
\hline 1 Jan 2012 & 1 Jan 2041 & $3.50 \%$ & $130,000,000.00$ & 18.67 \\
\hline
\end{tabular}

Table 15: Basic data on selected government bond

Source: own calculations

minimum guaranteed return that affects both sides of a pension fund's balance sheet.

The rise of interest rates would increase the required yield of our debt securities by 100 basis points. Each group of investments can be considered a single debt security with a fixed (average) coupon and annual or semiannual coupon payments.

The parallel shift in the yield curve has no effect on coupon payments (as coupons are fixed), but it does alter the returns from interest on interest. The coupons from corporate bonds maturing after the first 6 months (semiannually) have already been reinvested at a higher reinvestment rate. The coupons from government bonds that mature at the end of the year (annually) have not yet been reinvested. Because the required yield has increased, the market value of all debt securities has decreased. If the modified duration of a pension fund's assets was perfectly matched to the modified duration of a pension fund's liabilities, the change in interest on interest would be offset by the change in price. Because this is not the case, the reinvestment risk and interest rate risk are not perfectly hedged. The pension fund's total annual return is therefore only $1,030,531.13$ EUR or $0.79 \%$.

The minimum guaranteed return was calculated as the average yield to maturity of all Slovenian government bonds, with a term to maturity of 1 year or more. As the average yield to maturity of government bonds increases, the minimum guaranteed return increases. However, because the guaranteed return is calculated every 6 months (and remains fixed for the following 6 months), it will only affect the required rate of return on the pension fund's liabilities in the second half of the year. On an annual level, the minimum guaranteed return will therefore increase only by half, i.e. 50 basis points to
$2.80 \%$. The new guaranteed value of the fund would be $126,958,000.00$ EUR.

Thus higher guaranteed return must be added on top of the pension fund's guaranteed value. Since the actual return is below the minimum guaranteed return, the difference must be covered by technical provisions. The management fee will also be deducted from technical provisions. Their total reduction is almost 4 million EUR. If we were testing the impact of a stock market decline, the reduction of technical provisions would be the same as a $31.24 \%$ decline in stock prices and a $-23.43 \%$ decline in mutual funds. Because debt securities represent most of the pension fund's portfolio, interest rate risk has the largest effect on the capitalization of the pension fund. Interest rate risk can be managed with the more accurate (modified) duration matching of assets and liabilities. It is also possible to hedge interest rate risk using the amortized cost valuation method.

For the selected pension fund it has been estimated that the average duration of liabilities is 18.68 years. In order to determine the liabilities' sensitivity to changes in the general level of interest rates, the modified duration of liabilities also has to be calculated. The pension fund manager has to attribute at least the minimum guaranteed return of $2.30 \%$ to liabilities every year. At the same time, the actual return must also suffice to cover the management fee of $1.20 \%$. The required return on liabilities thus amounts to a total of $3.50 \%$. Based on these data, the following can be calculated: 


\begin{tabular}{|c|c|c|c|c|c|}
\hline New return & $\begin{array}{c}\text { Coupon } \\
\text { payments }\end{array}$ & Interest on interes & Market value & Sum & The difference \\
\hline $2.00 \%$ & $84,994,000$ & $16,836,997.45$ & $151,099,000.00$ & $252,929,997.45$ & $5,741,028.27$ \\
\hline $2.50 \%$ & $84,994,000$ & $21,670,377.66$ & $144,781,000.00$ & $251,445,377.66$ & $4,256,408.47$ \\
\hline $3.00 \%$ & $84,994,000$ & $26,784,053.72$ & $138,775,000.00$ & $250,553,053.72$ & $3,364,084.53$ \\
\hline $3.50 \%$ & $84,994,000$ & $32,194,969.18$ & $130,000,000.00$ & $247,188,969.18$ & 0.00 \\
\hline $4.00 \%$ & $84,994,000$ & $37,921,080.57$ & $127,660,000.00$ & $250,575,080.57$ & $3,386,111.39$ \\
\hline $4.50 \%$ & $84,994,000$ & $43,981,415.71$ & $122,525,000.00$ & $251,500,415.71$ & $4,311,446.53$ \\
\hline $5.00 \%$ & $84,994,000$ & $50,396,135.26$ & $117,637,000.00$ & $253,027,135.26$ & $5,838,166.08$ \\
\hline
\end{tabular}

Table 16: Total return of bond at various levels of required return (in EUR)

Source: own calculations

future value of liabilities $=130,000,000.00 *(1+3.50$ $\%)^{18.68}=247,188,969.18$ EUR

$$
\text { modified duration of liabilities }=\frac{18.68}{(1+3.50 \%)}=18.05
$$

The estimated modified duration of liabilities thus equals 18.05. If the manager seeks to eliminate interestrate risk and reinvestment risk at the same time, he or she has to invest the pension fund's assets in investments whose modified duration matches the liabilities. In this case, the manager could purchase a government bond with a maturity of 29 years and a $3.50 \%$ coupon rate. The modified duration of this bond equals 18.04, which almost completely matches the liabilities.

The bond will be held for 18.68 years, which corresponds to the duration of our liabilities, and will then be sold at the market price valid at that time. In addition to interest payments, the total return of the bond is thus also affected by changes in the market price (interest-rate risk) and the return generated from the reinvestment of the interest payments already received (reinvestment risk). The estimate takes into account the presumption that the required return changes immediately after the purchase of the government bond and remains the same until it is sold. In addition, it is also presumed that the yield curve is flat and that it shifts upward or downward evenly for all maturities when the required return changes.

The table shows that if the required return remains unchanged (i.e., 3.50\%), the manager will generate a total return of EUR 247,188,969.18 from the bond, which is exactly the same as the estimated sum of future liabilities. Any change in the general level of interest rates does not affect the amount of coupon payments; however, interest on interest does change. If the required return is reduced, the manager will have to reinvest the interest already paid in new investments at the new, lower rate of return.
At the same time, due to the lower required return the manager will be able to sell the bond at a higher market price. The generated capital profit more than covers the loss of interest. The opposite applies when the interest rate increases. Due to reinvesting paid-out interest in more profitable investments, the income from interest on interest increases. However, with higher required return the bond has to be sold below its nominal value. Nonetheless, the additional income from interest more than covers the capital loss generated by selling the bond.

\section{Discussion and Recommendations}

To sum up, a great advantage of this strategy is that a change in the general level of interest rates never has a negative impact on the pension fund return. In fact, if the required return is changed significantly in either the positive or negative direction, the manager can generate a greater surplus of the actual return over the required return. The risk of a decrease in the investment market value due to an increase in the general level of interest rates (interest rate risk) and the risk of a decrease in the income from interest on interest due to a decrease in the general level of interest rates (reinvestment risk) cancel each another out. With precise matching of the duration of assets with the duration of liabilities, the actual pension fund return is never lower than the required return.

On the other hand, there are also some disadvantages to this strategy. In the long term, the actual return will never significantly exceed the required return. That is, the strategy limits the return that could be generated by investing in bonds with a duration that does not equal the duration of liabilities. In case of low interest rates, the manager can intentionally invest in short-term bonds and thus expose the pension fund to reinvestment risk. Anticipating that the interest rates will rise in the future, 
the manager will be able to reinvest the matured bonds and principals in more profitable investments, and thus boost the total return of the portfolio.

A further weakness of this strategy is also the fact that it demands constant adjustment of assets and liabilities. In our case, a one-off change in the general level of interest rates was presupposed, but in real life market interest rates change constantly. Changes in the required return cause changes in the duration of the portfolio. At the same time, the closer to the maturity date, the shorter the investment durations become. Due to these two factors the portfolio has to be constantly adjusted to the pension fund's liabilities, which incurs transaction costs.

In matching the duration of assets and liabilities one should also not forget the model of estimating the minimum guaranteed return. With greater changes in the general level of interest rates, the amount of guaranteed return will also change. The manager will have to find new investments that will correspond to the changed characteristics of the liabilities. Using the estimation method, a manager in Slovenia can do this in six months time. However, if the manager does not take action, due to the mismatch he or she will expose the fund's assets to interest-rate risk or reinvestment risk with all its positive and negative consequences.

It is possible for the manager of the fund to completely eliminate currency risk by only selecting investments that are denominated in the same currency as the pension liabilities are denominated in. Other investments would then only be included if they increase portfolio diversification and decrease price risk. Because there is no guaranteed return on technical provisions, this portion of the liabilities can be matched with equity investments that have a higher price risk. As long as the actual return is below the minimum guaranteed return, the manager will be forced to reduce the fund's exposure to riskier investments. As soon as the actual return exceeds the guaranteed return, technical provisions will rise and the manager will be able to increase the share of equity investments. With an accurate (modified) duration matching of assets and liabilities, the interest rate risk and reinvestment risk can be completely offset. Short-term interest rate volatility can be hedged with the amortized cost valuation method. The manager can also use the market value valuation, adjusting the duration of investments to expected interest rate movements. If interest rates are expected to rise, the manager can shorten the average duration of the portfolio. The manager will increase reinvestment risk and reduce the price risk of the debt securities portfolio. Returns (or interest on interest) from the reinvestment of matured bonds and coupon payments will more than offset the loss of the portfolio's market value. If interest rates are expected to fall, the manager will buy bonds with a longer duration than the duration of pension liabilities. This will increase the portfolio's price risk. Because the required returns will fall, bond prices will rise. The capital gain from the increased portfolio's market value will more than offset the reduced income from interest on interest.

As the interest rates rise or fall, the minimum guaranteed return changes. The manager can avoid the risk of underperforming the guaranteed return with partial portfolio indexation, where the guaranteed return is considered a benchmark. He can invest a part of the pension fund's assets into reference government bonds, used in the minimum guaranteed return calculation. Additional returns can be made investing in bonds of similar duration and credit risk, but with a higher yield to maturity. Allocating entire net premiums received in government bonds and prime corporate bonds will significantly reduce a pension fund's credit risk exposure. More risk can be avoided by investing the guaranteed return already earned in mutual funds with a properly diversified investment policy, with no significant restrictions to an individual industry or region. Technical provisions can be matched with investments in blue chip shares of companies with sound financial statements and high market capitalization. A fund's assets should be allocated only in those investments with a high turnover ratio (shares) or a market maker (bonds). For pension plan members at the age of 55 or above, the liquidity reserve should be formed from investments in bank deposits and short-term debt securities (treasury bills, certificates of deposit, commercial paper). In this way, the liquidity risk and biometric risks will be much easier to hedge. A pension fund's assets should also be managed in such a way that they retain their purchasing power. The risk of real asset value depreciation can be hedged with investments in bonds that are linked to inflation. This will help the manager earn a real rate of return regardless of the actual inflation rate in the future. During the asset allocation process, regulative and pension plan investment restrictions should always be obeyed.

After the pension fund's manager is able to implement the proper method of risk measurement and management, additional regulative restrictions on investments are no longer needed. Moreover, governments should never impose investment 
restrictions that would limit pension funds to the domestic market (i.e. restricting investments in foreign capital markets), forbid investments in shares or mutual funds or set a minimum limit of government securities. These restrictions hinder the diversification of the pension fund's assets and therefore make risk management more difficult.

\section{Conclusions}

Asset-driven portfolio management with the single investment goal of earning the highest return possible is not suitable for pension funds, as well as blind investment in those assets that are included in the minimum guaranteed return's calculation.

Asset-liability matching considerably eases the portfolio and risk management of a pension fund. With a selection of investments that are perfectly matched to the pension fund's liabilities, when considering duration, profitability and riskiness, it is possible to limit some of the financial risks, while others can even be hedged entirely, as we also intended to demonstrate in our paper, using empirical data from two Slovenian pension funds.

Using the information about plan members by age and gender and the structure of pension liabilities with the required rate of return, it is possible for the manager to determine the average duration, required rate of return and proper level of risk that would be suitable for liabilities. This information should help the manager select investments that are best fitted to the above-mentioned criteria. Once the investments are matched to liabilities by duration, return and risk are allocated, a portfolio sensitivity analysis can be run. This is actually a supplementary tool for a statistical model of a value-at-risk calculation. It helps the manager to define the risks that pose the greatest threat to a pension fund and take additional measures to protect the investments of pension plan members from financial market shocks.

We intended to demonstrate that after the manager is able to prudently handle a pension fund's assets, properly diversify, invest in liquid investments, define, measure and manage exposed risks, additional regulation restrictions on investments are no longer needed. Some restrictions can even hinder portfolio diversification and the risk management process. Therefore, governments should instead establish proper supervision over pension fund managers and keep today's active population appropriately informed about expected future pension benefits. 모

\section{Endnotes}

${ }^{1}$ The market value is the present value of future liabilities, discounted at proper interest rate. When interest rates rise, the present (or the market) value falls (Fabozzi 2000, p. 451).

${ }^{2}$ The consequences are the same in the case of inability to achieve the minimum guaranteed return in pension funds in Slovenia and other countries, where managers offer similar guarantees.

${ }^{3} \mathrm{~A}$ PBO ratio of $80 \%$ means that a pension fund has 0.80 EUR of assets available to cover 1 EUR of projected pension liabilities.

${ }^{4}$ In Slovenia, the process of creating and drawing provisions is explained in greater detail in the Pension and Disability Insurance Act (Uradni list Republike Slovenije 2006a, p. 11133-11134).

\section{References}

Boender, C.G.E., van Aalst, P.C. and Heemskerk, F. 1998. Modelling and management of assets and liabilities of pension plans in the Netherlands. In Worldwide Asset and Liability Modeling, edited by W.T.Ziemba, J.M.Mulvey, 561-580, Cambridge: Cambridge University Press.

Consigli, G. and Dempster, M.A.H. 1998. Dynamic stochastic programming for asset liability management, Annals of Operations Research 81:131-162.

Cox, J.C., Ingersoll, J.E. and Ross, S.A. 1985. A theory of the term structure of interest rates, Econometrica 53:385-407.

Davis, P.E. 2001a. Prudent Person Rules or Quantitative Restrictions: The Regulation of Long-Term Insitutional Investors' Portfolios. Uxbridge: Brunel University.

Davis, P.E. 2001b. Portfolio Regulation of Life Insurance Companies and Pension Funds, Paris: Organisation for Economic Co-operation and Development.

Davis, P.E. 2002. Pension Fund Management and International Investment - A Global Perspective. London: The Pension Institute.

Dert, C.L. 1995. Aseet liability management for pension funds: a multistage chance constrained programming approach. PhD thesis, Erasmus University Rotterdam.

Dupacova, J. and Polivka, J. 2009. Asset-liability management for Czech pension funds using stochastic programming. Annals of Operations Research 165 (1): 5-28.

Fabozzi, F.J. and Fabozzi, T.D..ed. 1989. Bond Markets, Analysis and Strategies. 1th ed. New Jersey: Prentice -- Hall.

Fabozzi, F. J. 2000. Bond Markets, Analysis and Strategies. 4th ed. New Jersey: Prentice - Hall.

Hess, T. 2000. Asset-Liability Management for Insurers. Zurich: Swiss Reinsurance Company, Economic Research \& Consulting.

Hilli, P.,Koivu, M., Pennanen, T., and Ranne, A. 2003. A stochastic programming model for asset liability management of a Finnish pension company, Stochastic Programming E-Print Series 2003-9. (database online) http://www.edoc.hu-berlin.de/series/speps/2003-9/PDF/9.pdf (accessed May 13, 2011).

Holmes, A. 2002. Risk Management. Oxford: Capstone Publishing.

Jacob, D., Lord, G. and Tilley, J. 1987. A general framework for pricing contingent cash flows. Financial management 16 (3):5-14. 
Kapitalska družba. 2011. Letno poročilo za leto 2010 za Kapitalski vzajemni pokojninski sklad (Annual report for 2010 for Capital Mutual Pension Fund). Ljubljana: Kapitalska družba.

Kouvenberg, R. 2001. Scenario generation and stochastic programming models for asset liability management. European Journal of Operations Research 134:279-292.

Laboul, A. 2006. Pension Markets in Focus. 3nd ed. Paris: Organisation for Economic Co-operation and Development.

Moja naložba. 2012. Financial information, internal data.

Norris, P. and Epstein, S. 1989. Funding the immunizing investment for insurance liabilities: the case of the SPDA. Society of Actuaries Study Note 380-22-91, Schaumberg, Illinois: Society of Actuaries.

OECD - Organisation for Economic Cooperation and Development 2005. Financial Market Trends: Ageing and Pension System Reform (Implications For Financial Markets And Economic Policies). Paris: Organisation for Economic Co-operation and Development, november 2005.

OECD - Organisation for Economic Cooperation and Development 2007. Developments in Pension Fund Risk Management in Selected OECD and Asian Countries. Paris: Organisation for Economic Cooperation and Development.

Pacific Investment Management Company. 2007. Bond Basics: Liability-Driven Investing. (database online) http://www2.pimco.com/pdf_uk/LDI_Basics_Europe_Dec06.pdf. (accessed June 26, 2011).

Reilly, F.K., Norton, E. A. 1999. Investments. 5nd ed. Forth Worth: The Dryden Press.

Uradni list Republike Slovenije (Official gazette of the Republic of Slovenia). 2006a. Zakon o pokojninskem in invalidskem zavarovanju (uradno prečiščeno besedilo) (ZPIZ-1-UPB4). Uradni list RS 109:1108511153.

Uradni list Republike Slovenije (Official gazette of the Republic of Slovenia). 2006b. Sklep o izjavi o naložbeni politiki ter o obvladovanju tveganj pokojninskega sklada. Uradni list RS 137:15454 - 15457.

Van der Meer, R.A.H. 1989. Matching bij pensioenfondsen van vitaal belang. Tijdschrift voor Financieel Management, september/oktober 5:20-28.

Yermo, J. 2001. A Proposal for Developing a Taxonomy of Private Pension Systems. Paris: Organisation for Economic Co-operation and Development. 